University of Nebraska - Lincoln

DigitalCommons@University of Nebraska - Lincoln

2018

\title{
African Lion (Panthera leo) Space Use in the Greater Mapungubwe Transfrontier Conservation Area
}

\author{
Andrei Snyman \\ Mashatu Research \\ Edward Raynor \\ University of Nebraska-Lincoln, edwardraynor@gmail.com \\ Chris Chizinski \\ University of Nebraska-Lincoln, cchizinski2@unl.edu \\ Larkin Powell \\ University of Nebraska-Lincoln, Ipowell3@unl.edu \\ John Carroll \\ University of Nebraska-Lincoln, jcarroll2@unl.edu
}

Follow this and additional works at: https://digitalcommons.unl.edu/natrespapers

Part of the Natural Resources and Conservation Commons, Natural Resources Management and Policy Commons, and the Other Environmental Sciences Commons

Snyman, Andrei; Raynor, Edward; Chizinski, Chris; Powell, Larkin; and Carroll, John, "African Lion (Panthera leo) Space Use in the Greater Mapungubwe Transfrontier Conservation Area" (2018). Papers in Natural Resources. 959.

https://digitalcommons.unl.edu/natrespapers/959

This Article is brought to you for free and open access by the Natural Resources, School of at DigitalCommons@University of Nebraska - Lincoln. It has been accepted for inclusion in Papers in Natural Resources by an authorized administrator of DigitalCommons@University of Nebraska - Lincoln. 
See discussions, stats, and author profiles for this publication at: https://www.researchgate.net/publication/325068328

\section{African Lion ( Panthera leo ) Space Use in the Greater Mapungubwe Transfrontier Conservation Area}

Article $\cdot$ October 2018

DOI: $10.3957 / 056.048 .023001$

CITATIONS

5 authors, including:

Andrei Snyman

Mashatu Research, Botswana

9 PUBLICATIONS 52 CITATIONS

SEE PROFILE

Christopher Chizinsk

University of Nebraska at Lincoln

54 PUBLICATIONS 418 CITATIONS

SEE PROFILE

Some of the authors of this publication are also working on these related projects:

Spatial ecology of prairie-chicken boom chorus View project

Bonobo occurrence as measured by landscape \& local metrics View project
Edward J. Raynor

United States Department of Agriculture

26 PUBLICATIONS 53 CITATIONS

SEE PROFILE

7. Larkin A. Powell

University of Nebraska at Lincoln

129 PUBLICATIONS 1,354 CITATIONS

SEE PROFILE 


\title{
African lion (Panthera leo) space use in the Greater Mapungubwe Transfrontier Conservation Area
}

\author{
Andrei Snyman $^{1 *}(\mathbb{D})^{\S}$, Edward Raynor $^{2}($ (D) $)$, Chris Chizinski $^{2}$ (D), \\ Larkin Powell $^{2}$ (D) \& John Carroll ${ }^{2}$ (D) \\ ${ }^{1}$ Mashatu Research, Northern Tuli Game Reserve, P.O. Box 26, Lentswe Le Moriti, Botswana \\ ${ }^{2}$ School of Natural Resources, University of Nebraska, Lincoln, NE 68583, U.S.A. \\ Received 28 September 2017. To authors for revision 27 November 2017. Accepted 15 April 2018
}

\begin{abstract}
Large carnivores are key drivers of ecosystem structure and function, yet their populations are declining worldwide. African lion (Panthera leo) populations have decreased significantly in recent decades with an estimated 23000 lions left in Africa. Successful conservation efforts rely on a sound understanding of how animals utilize their surrounding habitat. We used movement data from GPS collars to investigate patterns and drivers of seasonal space use by free-roaming lions in the Greater Mapungubwe Transfrontier Conservation Area (GM-TFCA). We developed individual and population-level resource utilization functions (RUF) from 2008 to 2015. RUFs relate non-uniform space use within a home range to landscape metrics in a multiple regression framework. We identified six landscape features hypothesized a priori to be good predictors of lion space use: land use, land cover, elevation, terrain ruggedness, distance to human settlements and rivers. Only elevation during the dry season was a significant factor detected for lion space use $(\hat{\beta} \pm S . E).(-0.278 \pm 0.107, \mathrm{Cl}=$ $-0.4881,-0.0676)$. Across seasons, lions varied in their avoidance of human settlements, but 12 of $18(67 \%)$ individuals selected areas within their home ranges that were farther from human settlements. Lions moved randomly across the landscape independent of vegetation type regardless of season. In season-specific analyses, some lions avoided human settlements (dry season: $45 \%$, [ $n=10]$ utilized areas farther from settlements; wet season: $50 \%$ $[n=9])$. The lack of avoidance of settlements by some lions in our study also confirms that individual variation among lions can lead to human-wildlife conflicts. Perhaps the most critical observation from our study is that individual lions acted very differently as they used the landscape, which suggests the need for management plans to be landscape and case-specific.
\end{abstract}

Keywords: African lion, Botswana, carnivore, Panthera, resource utilization, savanna, space use.

\section{INTRODUCTION}

Successful conservation efforts rely on a sound understanding of how animals utilize their surrounding habitat. Habitat selection by large carnivores has been widely investigated (Stephens \& Krebs, 1986; Funston et al., 2001; Crawshaw \& Quigley, 1991; Hopcraft et al., 2005; Balme et al., 2007; Mosser et al., 2009; De Boer et al., 2010; Vlaeix et al., 2012; Petrunenko et al., 2016) with prey abundance and catchability of prey (Hopcraft et al., 2005; Balme et al., 2007; Hebblewhite et al., 2005) being key factors in driving most large terrestrial carnivores in how they utilize the land-

*To whom correspondence should be addressed. E-mail: andrei.snyman@gmail.com scape. Like most large terrestrial carnivores, African lions (Panthera leo) are difficult to conserve in the wild because they require large home ranges, they have a diet that typically includes large prey, they occur at low densities and can pose a significant risk to human safety (Cardillo et al., 2004; Cardillo et al., 2005; Carbone et al., 1999; Purvis et al., 2000, Holmern et al., 2007, Packer et al., 2005; Hopcraft et al., 2005). Consequently, lion populations have decreased significantly in recent decades, both in numbers and geographic range, with an estimated 23000 free-ranging lions left in Africa (Riggio et al., 2012; IUCN, 2013; Bauer et al., 2015).

Lions are opportunistic stalk-and-ambush predators (Schaller, 1972; Van Orsdol, 1984; Hayward \& Kerley, 2005) and select landscape features that 
increase hunting success and catchability of prey, such as dense cover, erosion gullies and watering holes (Funston et al., 2001; Hopcraft et al., 2005; Mosser et al., 2009). As large and visible carnivores that are also found in groups, lions are particularly at risk from human persecution and frequently sustain high levels of anthropogenic mortality (Woodroff \& Ginsberg, 1998; Woodroffe, 2000; Snyman et al., 2015), leading to behavioural alteration with regards to proximity to humans (Oriol-Cotterill et al., 2015). For example, Snyman et al. (2015) found that within an 11-year period at Botswana's Northern Tuli Game Reserve over $94 \%$ of adult lion mortality occurred outside protected area borders.

We investigated lion resource use in the Greater Mapungubwe Transfrontier Conservation Area (GM-TFCA) using resource utilization functions (RUF) (Marzluff et al., 2004), also referred to as third-order habitat selection (Johnson, 1980). RUFs calculate a probabilistic measure of nonuniform space use within an animal's home range and then use a multiple regression framework to relate space use to landscape features while accounting for spatial autocorrelation among multiple consecutive locations from the same individual. Regression coefficients from the RUF can be used to draw inferences about the direction and magnitude of relationships between intensity of space use and values of selected resources at either an individual or a population level (Marzluff et al., 2004, Kertson et al., 2011). The primary objective of our eight-year study was to determine the potential effects of human development and landscape characteristics on seasonal land use of free-roaming African lions. Because lions are ambush predators (Schaller, 1972; Van Orsdol, 1984; Hayward \& Kerley, 2005), we hypothesized that lions would closely associate with denser vegetation and rivers, where the catchability of prey is higher compared with non-riparian areas (Hopcraft, 2005). Additionally, we hypothesized that lions would avoid human settlements as these areas are perceived as sources of mortality (Woodroffe, 2001; Oriol-Cotterill et al., 2015).

\section{METHODS}

Permission and ethical clearance for this research was granted by the Botswana Ministry of Environment, Wildlife and Tourism (EWT 8/36/4 XXXIII (48)). Within the GM-TFCA $\left(4872 \mathrm{~km}^{2}\right)$, our primary study areas included in Botswana, the Northern Tuli Game Reserve (NTGR, $720 \mathrm{~km}^{2}$ ); in South Africa, Mapungubwe National Park (MNP,

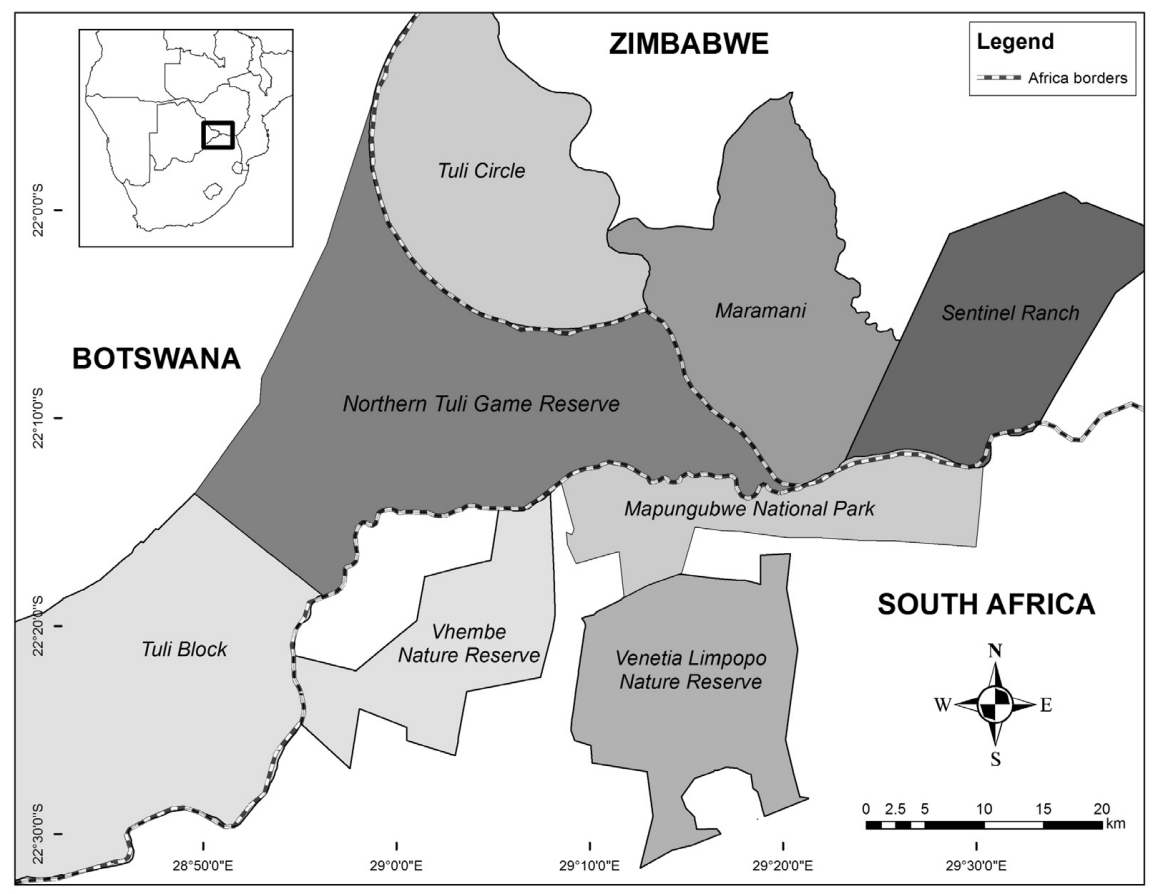

Fig. 1. The Greater Mapungubwe Transfrontier Conservation Area bordering Botswana, South Africa and Zimbabwe in Southern Africa. Image from Peace Parks Foundation. 
Table 1. Summary of the listed properties, their size, and potential impact on wildlife in the Greater Mapungubwe Transfrontier Conservation Area at the time of the study (2007-2015).

\begin{tabular}{llcccc}
\hline Name & Country & $\begin{array}{l}\text { Size } \\
\left(\mathrm{km}^{2}\right)\end{array}$ & $\begin{array}{c}\text { Photographic } \\
\text { tourism }\end{array}$ & Safari hunting & Lion hunting \\
\hline Northern Tuli Game Reserve & Bots & 720 & $\mathrm{X}$ & & \\
Mapungubwe National Park & RSA & 210 & $\mathrm{X}$ & & \\
Vhembe Private Nature Reserve & RSA & 230 & $\mathrm{X}$ & $\mathrm{X}$ & $\mathrm{X}$ \\
Tuli Circle & Zim & 390 & & $\mathrm{X}$ & $\mathrm{X}$ \\
Sentinel Ranch & Zim & 330 & $\mathrm{X}$ & $\mathrm{X}$ & \\
Venetia Limpopo Nature Reserve & RSA & 330 & $\mathrm{X}$ & $\mathrm{X}$ & $\mathrm{X}$ \\
\hline
\end{tabular}

$280 \mathrm{~km}^{2}$ ), Vhembe Private Nature Reserve (VPNR, $307 \mathrm{~km}^{2}$ ), Venetia Limpopo Nature Reserve (VLNR, $330 \mathrm{~km}^{2}$ ); and in Zimbabwe, Sentinel Ranch (SR, $\left.320 \mathrm{~km}^{2}\right)$ and the Tuli Circle (TC, $416 \mathrm{~km}^{2}$ ) (Fig. 1, Table 1).

Between May 2007 and October 2015 we captured and fitted GPS collars to a total of nine adult (4+ years) lions (7 males, 2 females) (Africa Wildlife Tracking, Pretoria, South Africa) throughout our study area. Based on an average collar life of 2 years, and re-collars of some animals, this represented a total of 26 lion-years' of movement data. GPS collar readings ranged between 4 and 8 hourly readings per day. Lions were captured using standard lion capture techniques (Smuts et al., 1977). Lions were immobilized with a combination of $0.03-0.05 \mathrm{mg} / \mathrm{kg}$ medetomidine $20 \mathrm{mg} / \mathrm{ml}$ (Kyron Laboratories, South Africa) and 0.5$1.0 \mathrm{mg} / \mathrm{kg}$ Zoletil 100 (tiletamine-zolazepam) (Virbac, South Africa) based on estimated weight by dart injection by a Botswana registered wildlife veterinarian. Medetomidine was reversed with $0.2 \mathrm{mg} / \mathrm{kg}$ atipamezole $5 \mathrm{mg} / \mathrm{ml}$ (Pfizer, South Africa) administered intramuscularly.

We calculated lion home range size in ArcGIS (ESRI, Redlands, California) extension software ArcMET (Wall, 2014) by using a 95\% kernel density estimate (KDE) isopleth. Kernel bandwidth also called a smoothing parameter, reference ( $\mathrm{h}_{\mathrm{REF}}$ ) (Worton, 1989) was used for the calculations, due to its objectivity and computational simplicity. KDE spatial resolution was set at $30 \times 30 \mathrm{~m}$ in keeping consistency with all other spatial data used for this study. The average height of each utilization distribution (UD, Van Winkle, 1975) was calculated using Focal Statistics on a $3 \times 3$ cell basis. After UDs were converted from raster to point format types, the Extract Multi Values to Points feature in ArcGIS was used to assign values to each location from the covariates in this study.
To provide a normal distribution, the natural log (100-UD) was used as the response variable whereby higher values indicate higher levels of utilization. We square root-transformed elevation $(m)$, distance to rivers $(m)$ and settlements $(m)$, and used the log of terrain ruggedness index before RUF analysis. Variance Inflation Factor (VIF) in software R (R Development Core Team, 2014) was used to determine multicollinearity between our set of variables (package 'usdm' (Naimi, 2015). Any variable with a VIF larger than 10 was excluded from that particular individual's model (Dormann et al., 2013).

\section{Utilization distributions and resource utilization functions}

We created UDs to investigate how environmental and anthropogenic factors affected lion space use in the study area by quantifying third-order selection, which is the differential space use patterns of an individual within its home range (Johnson, 1980). RUFs are considered a continual probabilistic density function (Silverman, 1986) that calculate an individual's space use where the height of a UD at each location represents the level of utilization relative to the rest of the locations while accounting for spatial autocorrelation (Van Winkel, 1975; Kernohan et al., 2001; Hepinstall et al., 2005). A particular strength of using the UD approach is estimating a UD for each study animal, which treats the animal as a primary sampling unit (Otis \& White, 1999; Erikson et al., 2001).

The landscape features that drive variation between the UD values of each location can be determined using multiple linear regression. Positive $(+)$ and negative $(-)$ signs indicate whether use increases or decreases with variation in the quantity of that resource (Marzluff et al., 2004). Standardized coefficients allow for comparisons 
between variables, determines the statistical significance of each variable using $95 \% \mathrm{Cls}$, ranks relative importance of variables by their absolute value, and determines the positive or negative influence of each variable on animal space use, whereas unstandardized coefficients are used for predictive mapping occurrence (Marzluff et al., 2004). In this study, we focus on the standardized coefficients given their statistical relevance for testing our hypotheses: relative preference for riparian areas and avoidance of human settlements.

Spatial autocorrelation, often evident in ecological studies (Schiegg, 2003), was accounted for by the RUF using maximum likelihood procedure with a Matern correlation function (Marzluff et al., 2004). For each predictor variable, the mean standardized $\beta$ coefficient and associated variance were calculated using the Delta method (Powell, 2007). The standardized partial regression coefficients from each variable were estimated by

$$
\beta j=\hat{\beta} j \frac{s_{x j}}{S_{\mathrm{RUF}}}
$$

where $\hat{\beta} j$ is the maximum likelihood estimate of the partial regression coefficient from the multiple regression estimates (unstandardized $\beta$ ), $S_{x j}$ is the standard deviation of the resource value $j$, and $S_{\text {RUF }}$ is the estimate of the standard deviation of the UD values (Marzluff et al., 2004). As each lion was taken to be independent from year to year (Kertson et al., 2011), population-level estimates were calculated by averaging the RUFs across all lions with variance calculated to include both between and within lion variance (Marzluff et al., 2004). Significant predictors of space use were identified by not having $95 \%$ confidence intervals that overlapped with zero (Marzluff et al., 2004). All means are given $\pm \mathrm{S}$.E. All statistical analysis was done using R (version 2.13, R Core Development Team, 2014). RUF analyses were performed using the package ruf.fit (http://csde.washington.edu/ handcock/ruf/).

An overall mean from the population level is useful to evaluate what the lion population is responding to overall, whereas the inter-individual level results are useful to tease apart what factors could have attributed to each specific lion's space use for that particular year (Kertson et al., 2011).

\section{Covariates}

We identified environmental and anthropogenic features of the landscape that were hypothesized a priori to be good predictors of lion space use.
Covariates included: land cover (Funston et al., 2001; Hopcraft et al., 2005; Balme et al., 2007; Davies et al., 2016), land use (Woodroffe, 2000; Woodroffe, 2001), elevation, terrain ruggedness (Hopcraft et al., 2005; van Dyk \& Slotow, 2003), distance to human settlements (Valeix et al., 2012; Elliot et al., 2014; Cotteril et al., 2015), and distance to rivers (Hopcraft et al., 2005; Balme et al., 2007; Mosser et al., 2009).

Inferences from standardized coefficients with $95 \%$ confidence intervals that did not overlap with zero were considered significant predictors of a particular resource (Marzluff et al., 2004). For example, for distance metrics, positive values mean an avoidance of that landscape feature whereas negative values would indicate selection. For terrain ruggedness and elevation, positive standardized $\beta$ coefficients indicate selection of rugged terrain or elevation, whereas the opposite is true for negative values. The relative importance of landscape metrics was ranked using the magnitude of the mean standardized $\beta$ coefficients. Wet and dry seasons were defined as ranging from November to March and April to October, respectively.

\section{RESULTS}

Lions were tracked on average 808 (S.E. $=272$ ) days resulting in a total of 26345 GPS fixes with an average of 2927 fixes per lion (S.D. $=2131$, ranging from 900 to 8137$)$. Lions moved on average 1477 m (S.E. = 409, $n=9$ ) between 6-hr fixes. Furthermore, only nocturnal GPS readings were used in the analysis, providing insight into lion spatial ecology during the period when they are most active (Hayward \& Slotow, 2009)

\section{Resource selection}

Due to multicollinearity, the weighted importance of land use to lions was excluded from the RUF model and instead calculated by using the percentage of GPS locations that fell within four land-use zones: protected, semi-protected, unsafe and hostile. Factors considered to influence lion survival and safety included: human tolerance towards lions (measured by interviews and interactions with the landowners), the risk of being shot, the presence of livestock and whether lions were known to have been shot and killed in each zone (Table 2). Protected and semi-protected areas categorized in this study made up $42 \%$ of the total study area and contained $95 \%$ of all recorded lion GPS locations (Table 2). It is worth 
noting that $73 \%$ of lion locations were recorded in only $14 \%$ of the study area (Table 2 ).

\section{Population-level}

We estimated population level RUFs for lions in the GM-TFCA during the dry and wet seasons between 2008 and 2015, with an average of 183 locations per individual for each 6-month season. Mean standardized $\hat{\beta}$ coefficients at the population level across seasons provided little evidence for landscape-level influences on lion resource utilization as all landscape composition variables overlapped zero (Table 3). Mean standardized $\hat{\beta}$ coefficients for elevation ( $\hat{\beta} \pm$ S.E., 95\% Cl's) $(-0.190 \pm 0.108, \mathrm{Cl}=-0.401,0.021)$ and distance to human settlements $(0.173 \pm 0.105, \mathrm{Cl}=-0.034$, 0.379 ) provided some evidence for low elevation and avoidance of human settlements driving space use (Fig. 2, Table 3). When we evaluated data by season, we found that strong evidence for avoidance of elevation $(-0.278 \pm 0.107, \mathrm{Cl}=$ $-0.4881,-0.0676)$ on space use during the dry season, which suggests that lions at the population level are selecting lower-lying areas in the study area (Fig. 2). We found little evidence for landscape feature effects on space use during the wet season, although there was some evidence that low elevation may have driven space use during wet months (Fig. 2).

\section{Individual-level - Combined season}

We found no evidence that land cover affected resource selection within home ranges at the individual level across seasons (Table 3). However, the geographic and topographic features of the study area were significant drivers of space use. We found strong support for effects of elevation, distance to rivers and settlements, and to a lesser degree terrain ruggedness, as predictors of space use (Table 3). Eighty-three per cent of lions $(15 / 18)$ showed effects of elevation on space use, and $77 \%$ of our study individuals (14/18) preferred lowlands within their home ranges. Lions showed a strong avoidance of proximity to human settlements; $66 \%$ (12/18; Table 3) of individuals in our sample selected for areas within their home range that were farther from human settlements $(\bar{x}$ (range): $3925.3 \mathrm{~m}$ (30.3-10457.5; Table 4). The directionality of space use as regards distance to rivers was mixed; $44 \%(8 / 18)$ of lions selected areas closer to rivers, and nearly $17 \%(3 / 18)$ strongly selected for regions farther from rivers (1774.1 m (0-4449.0; Table 4). Space use of the 


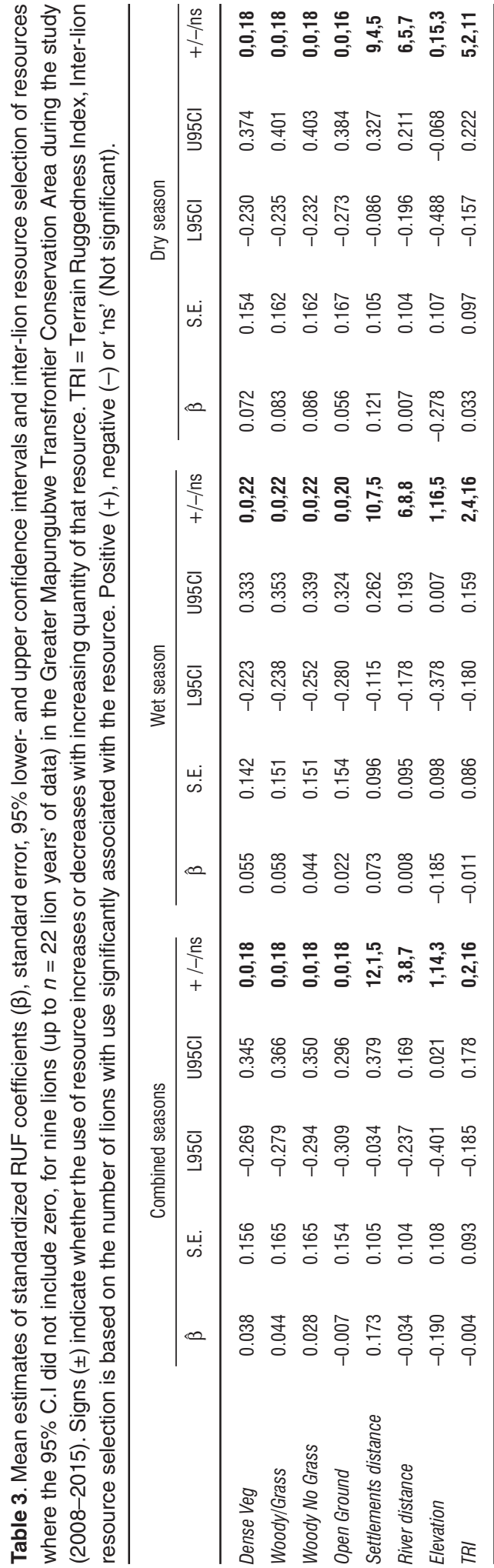

majority of lions ( $89 \%, n=16 / 18)$ was not affected by terrain ruggedness, only $11 \%(2 / 18)$ showed avoidance of rough terrain $3.5 \mathrm{~m}$ (1.6-9.0; Table 4).

\section{Inter-individual level - Dry season}

The mean standardized $\hat{\beta}$ coefficients for the four vegetation classes provided no evidence of an effect of vegetation type on space use (Table 3, Fig. 2). However, we did find that geographic and topographic variables were important factors underlying lion distribution (Table 3). The majority, $83 \%(15 / 18)$, of lions showed a significant preference within their home range for lower-lying areas (Table 3) with three having no preference. Avoidance of human settlements in the dry season decreased slightly from the combined season; $50 \%(9 / 18)$ of lions avoided areas close to human settlement $4988.8 \mathrm{~m} \mathrm{(42.8-17083.9)}$ and four lions $(22 \%)$ selected areas closer to people $2595.2 \mathrm{~m}$ (30.3-10457.5, Table 4). Thirty-three per cent $(6 / 18)$ of lions selected areas away from rivers $1373 \mathrm{~m}(0.0-4449.0)$, while five lions (25\%) selected areas closer to rivers $25.95 .2 \mathrm{~m}$ (30.310457.5, Table 4). Sixty-one per cent (11/18) of lions did not show any evidence of preference related to terrain ruggedness, while five lions $(27 \%)$ indicated selection for rougher terrain 5.4 (1.6-17.2); two lions (11\%) showed a selection of smoother terrain 3.9 (1.6-16.9).

\section{Inter-individual level - Wet season}

Vegetation type was not a driver of space use during the rainy season (Fig. 2). However, we detected substantial variability among lions in their response to elevation, distance to rivers and human settlements, and terrain ruggedness (Table 3, Fig. 2). Sixteen of 22 (73\%) lions showed some evidence for the high use of lower-lying areas $558.8 \mathrm{~m}$ (484.0-715.0, Table 4), yet only one lion selecting low-lying areas (Table 3, Fig. 2). Forty-five per cent (10/22) of lions used areas farther away from people $4335.7 \mathrm{~m} \mathrm{(30.3-}$ $16714.2)$ and $31 \%(7 / 22)$ selected regions closer to human habitation $3029.3 \mathrm{~m}$ (30.3-14596.0). Thirty-six per cent $(8 / 22)$ of lions preferred areas closer to rivers $975.4 \mathrm{~m}(0.0-4426.0)$, whereas $27 \%(6 / 22)$ lived in areas farther away from river systems $1474.9 \mathrm{~m}$ (0.0-4520.9). Seventy-two per cent of lions (16/22) showed no evidence of effects of terrain ruggedness within their home range; four lions $(18 \%)$ selected areas with lower ruggedness 3.6 (1.6-16.9), and one lion selected areas that were rugged. 

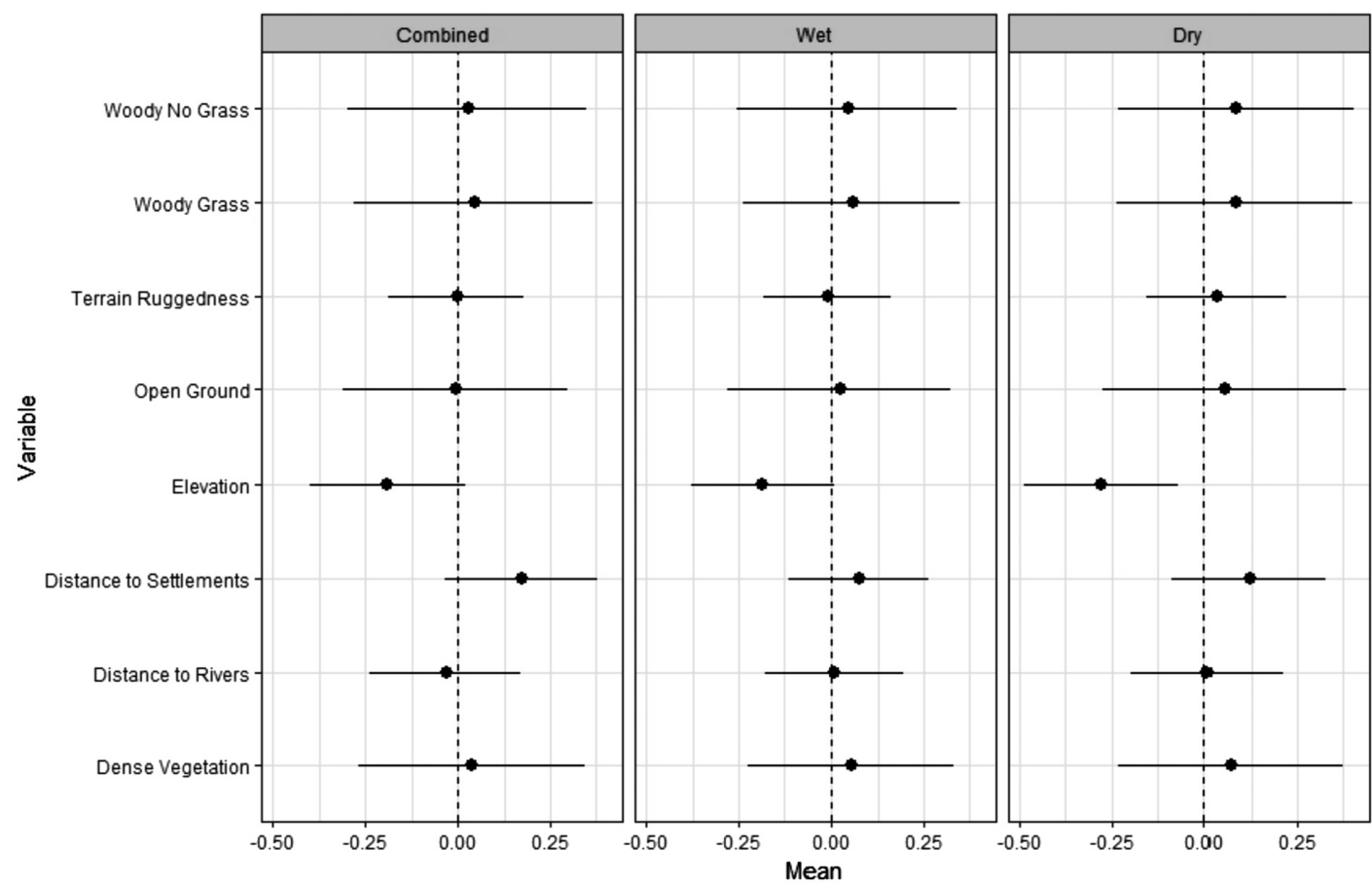

Fig. 2. Mean standardized $\beta$ coefficients $(95 \% \mathrm{Cl})$ for lion resource utilization at the population level for combined, wet (Nov-Mar) and dry (Apr-Oct) seasons in the Greater Mapungubwe Transfrontier Conservation Area during the study period (2007-2015). Signs (+/-) indicate whether the use of the specific resource increases or decreases with increasing quantity of that resource.

Table 4. Mean (range) values of environmental and anthropogenic features of the landscape used by African lions (Panthera leo) in the Greater Mapungubwe Transfrontier Conservation Area during the study (2008-2015). TRI = Terrain Ruggedness Index. Positive (+), negative (-) or 'ns' (not significant).

\section{Landscape features}

\section{Combined season}

$$
+\quad \text { - NS }
$$

\begin{tabular}{lccc} 
Settlement distance $(\mathrm{m})$ & $3925.3(30.3-10457.5)$ & $2381.7(95.7-9249.1)$ & $2451(30.3-10457.5)$ \\
River distance $(\mathrm{m})$ & $1774.1(0.0-4449.0)$ & $747.7(0.0-4155.6)$ & $1434.5(0.0-4449.0)$ \\
Elevation $(\mathrm{m})$ & $584.4(512.0-644.0)$ & $553.6(0.0-721.0)$ & $570.4(492.0-617.0)$ \\
TRI & $\mathrm{na}^{*}$ & $3.5(1.6-9.0)$ & $4.2(0.0-17.6)$ \\
\hline
\end{tabular}

\begin{tabular}{lccc}
\hline & & Wet season & \\
& + & - & NS \\
\hline Settlement distance & $4335.7(30.3-16714.2)$ & $3029.3(30.3-14596.0)$ & $3058.8(67.7-11647.9)$ \\
River distance & $975.4(0.0-4426.0)$ & $975.4(0.0-4426.0)$ & $927.4(0.0-4121.9)$ \\
Elevation & $574.4(492.0-617.0)$ & $558.8(484.0-715.0)$ & $562.6(505.0-660.0)$ \\
TRI & $4.6(1.8-13.3)$ & $3.6(1.4-18.5)$ & $3.9(1.4-17.6)$ \\
\hline & + & Dry season & NS \\
\hline Settlement distance & $4988.8(42.8-17083.9)$ & $2595.2(30.3-10457.5)$ & $2706.9(90.8-16160.3)$ \\
River distance & $1373.0(0.0-4449.0)$ & $677.9(0.0-3878.8)$ & $1294.2(0.0-4424.3)$ \\
Elevation & na & na & na \\
TRI & $5.4(1.6-17.2)$ & $3.9(1.6-16.9)$ & $3.7(0.0-17.3)$ \\
\hline
\end{tabular}

${ }^{*}$ na $=$ not available. 


\section{DISCUSSION}

Large carnivores are a critical component of any ecosystem, and their extirpation has impacts that may reverberate throughout ecosystems (Estes et al., 2011, Ripple et al., 2010, 2014). Thus, understanding how they utilize their landscape is becoming increasingly important given their global population declines (Packer et al., 2013, Ripple et al., 2010, 2014, Bauer et al., 2015). Lion populations in modern Africa can accurately be described as fragmented and scattered across the continent (IUCN, 2013; Bauer et al., 2015). Conservation of smaller, isolated lion populations has become essential in the quest to curb the current decline (Riggio et al., 2016). Understanding what factors drive lion space use that underlies landscape-level distribution is essential for their conservation efforts.

\section{Vegetation}

In this study, none of the four vegetation classifications (dense vegetation, woody-grass, woodyno-grass, and open ground) showed any notable selection by lions at both the population and individual levels, which implies that lions were not selecting any particular type of land cover in the study periods investigated here. With the majority $(95 \%)$ of lion GPS locations within less than half $(42 \%)$ of the total study area (Table 2 ), the contrast from our findings to that of Hopcraft et al. (2016) and Davies et al. (2016) could be because lions are forced to utilize all available habitat within the protected and semi-protected classified landscapes.

\section{Distance to rivers}

Proximity to riverbeds is an important factor underlying lion space use as these areas provide dense cover for both hunting and shade. The linear features also offer greater opportunities for encountering prey seeking water and suitable food resources (Hopcraft et al., 2005; Mosser \& Packer, 2009; De Boer et al., 2010). However, dry and wet seasonal differences in selection for riverbeds might be observed as illustrated by Lehmann et al. (2008). Due to a wider abundance and distribution of water sources during the wet season, prey tends to be widely distributed. Thus, prey density is often less dense in high-risk areas such as riverbeds during the wet season. In contrast, prey animals are forced to enter high-risk zones to gain access to water and food in the dry season (Lehmann et al., 2008; De Boer et al., 2010). We found that proximity to rivers had little influence on space use at the population level during the wet, dry and combined seasons. Even at the interindividual level, our analyses found no clear indication that lions selected areas closer to rivers during the dry season or further away in the wet season. During both the wet and dry season, approximately one-third of our sample of lions showed selection for areas of their home range that were close to river systems, one-third showed selection for areas farthest from rivers, and onethird showed no selection with regard to distance from rivers. We believe that these results can be explained by a combination of both the size of the study area and the distribution of rivers and drainage lines classified in this study. Drainage lines and major rivers, such as the Limpopo, Shashe, and Motloutse River were all categorized as 'rivers' collectively, not primary or secondary river systems. Whether these rivers were flowing or not during our study would have also influenced prey distribution (Polis et al., 1997; Gaylard et al., 2003) and, by extension, lion space use.

\section{Elevation}

Elevation in the dry season was the only significant predictor of lion space use in our pooled analyses (population level). In addition, more than three-quarters of the individuals in our sample showed selection for lowland areas in the wet and dry seasons. Elevation has not, to our knowledge, been recorded as a major driver of African lion space use previously. Hopcraft et al. (2005) found that lions living on the plains of the Serengeti used view-sheds from rocky outcrops as a means to increase their view range. This effect, however, was not detected for lions living in the woodlands of the Serengeti (Hopcraft et al., 2005), which implies that lions in flatter geographic landscapes might use higher elevated vantage points as a fine-scale hunting tactic when they scan during hunting. We did not use a fine-scale approach in our study with specific viewsheds; rather, elevations were relative to the extent of the study area. One plausible argument for this finding is that lions from the GM-TFCA predominantly occupy territories that are situated in protected and semiprotected areas, and these protected areas are located in the lowlands of the study area.

\section{Distance to human settlements}

Lions are vulnerable to direct persecution by humans, and as with most large carnivores, their 
presence or absence in an area could be an ecosystem indicator to the degree of human impact on that region (Woodroffe, 2001). Oriol-Cotterill et al. (2015) found that lions showed behavioural changes in response to human-caused mortality risk that ultimately depended on environmental factors such as rainfall and moon phase. Their study also revealed that lion movements within a $1.5 \mathrm{~km}$ radius were affected by human presence. More importantly, Oriol-Cotteril et al. (2015) found that lions showed significantly, but not total, avoidance of pastoral lands.

Our results demonstrated that at the population level, pooling across all seasonal categories, lion space use within their home range did not appear to be influenced by the proximity to human settlements. However, at the inter-individual level, 67\% ( $n=12)$ of lions utilized areas within their home range further away from human settlements across both seasons. During the dry and wet seasons, lions at the individual level showed less clear preference to human-dominated areas with $45 \%(n=10)$ and $50 \%(n=9)$ utilizing areas further from human proximity, respectively. Our study used human presence/absence as a covariate and not human density, which may have shed further light on the subject.

We suggest that lions might have different avoidance tendencies for remote cattle posts, which are defined as small settlements, lived in by the people looking after their cattle that graze in the surrounding region, than for larger villages. Lions will move near cattle posts (A. Snyman, unpubl. data; OriolCotterill et al., 2015), but these movements are typically on dimly lit nights and at higher speeds (Valeix et al., 2012). In contrast, areas with human densities above 25 people/ $\mathrm{km}^{2}$ are believed to be highly unsuitable for lions and are avoided at all times (Woodroffe, 2000; Riggio et al., 2013), even though livestock associated with the villages are largely unattended. Therefore, avoidance patterns may be an example of fine-scale spatiotemporal adjustments, where larger villages were predominantly avoided (A. Snyman, unpubl. data). Our data on distance to settlements suggest that lions selected areas that were generally far from settlements for their home range, and this initial level of selection appears to have importance. Once established in a home range, our data suggest that lions were not as selective of where they moved within the home range, and this may have been due to a dependence on their initial choice of the boundaries of their home range to minimize disturbance from humans, which is similar to the findings of Kuiper et al. (2015). Furthermore, less than $5 \%$ of all reported cases of livestock depredation (31 cases from 702) over an 18-month period were attributed to lions (Brassine, 2014) in this study area; most depredation was caused by spotted hyaena (Crocuta crocuta) (>33\%). Brassine (2014) also found that over $47 \%$ of respondents to a questionnaire claimed that lions were completely absent from communal farmlands.

\section{Terrain ruggedness}

At both the population and individual levels, lions did not show any preference, or avoidance, for terrain ruggedness within their home ranges during any season. Unlike African wild dogs (Lycaon pictus) that prefer rugged terrain as a survival mechanism when choosing a denning site (Mills and Gorman, 1997; Van Dyk \& Slotow, 2003; Jackson et al., 2014), lions generally do not prefer rugged, mountainous terrain. The GM-TFCA has a wide variety of landscapes ranging from open plains to woodland thickets and wetlands, to cliffs and rugged sandstone ridges. Prey abundances are higher in lower-lying areas with nutrientrich soils that support a diverse flora community (Polis et al., 1997). Water sources are also predominantly found in riverbeds and human-made features such as dams and weirs, which are typically not found on ridges and rough mountainous terrain.

\section{CONCLUSION}

Our analyses showed that lions in the GM-TFCA did not respond to vegetation type, distance to rivers and terrain ruggedness within their home ranges. Rather, lions showed a preference for low-lying areas and utilized areas within their home range that were farther away from human settlements. Lions avoided areas that were classified as hostile and unsafe, with approximately three-quarters of locations in protected areas and a quarter of locations in semi-protected areas.

Our results inform conservation efforts for lions that typically exist in isolated populations. We suggest that conservation efforts to create corridors to improve lion movement and reduce mortality to increase population viability should focus on areas in the lower-lying regions of the GM-TFCA as well as areas away from human settlements. The wide-ranging nature of lions and the danger they pose to both livestock and human life makes conserving and protecting them a challenging and 
complex task. For example, the lack of avoidance of settlements by some lions in our study exemplifies the problems of trying to find a 'one-size-fitsall' solution for lion conservation. Indeed, individual variation among lions can result in a range of potential for human-wildlife conflicts. Perhaps the most critical observation from our study is that individual lions acted very differently as they used the landscape, which suggests the need for management plans that are landscape- and casespecific.

\section{ACKNOWLEDGEMENTS}

We thank the government of Botswana, the Ministry of the Environment, Wildlife, and Tourism and the Department of Wildlife and National Parks for permission to conduct this study (permit EWT 8/36/4 XXXIII (48)). We thank the landowners of the Northern Tuli Game Reserve and Mashatu Game Reserve, in particular Pete le Roux and David Evans for invaluable logistical support.

\begin{tabular}{lll}
\hline${ }^{\text {SORCID iDs }}$ & & \\
A.Snyman & (D) & orcid.org/0000-0001-8352-9345 \\
E. Raynor & (iD) & orcid.org/0000-0003-2483-4694 \\
C. Chizinski & (iD) & orcid.org/0000-0001-9294-2588 \\
L. Powell & (iD) & orcid.org/0000-0003-0570-4210 \\
J. Carroll & (iD) & orcid.org/0000-0001-7960-1092
\end{tabular}

\section{REFERENCES}

Balme, G., Hunter, L. \& Slotow, R. (2007). Feeding habitat selection by hunting leopards Panthera pardus in a woodland savanna: prey catchability versus abundance. Animal Behaviour, 74(3), 589-598.

Bartlam-Brooks, H.L., Bonyongo, M.C. \& Harris, S. (2013). How landscape scale changes affect ecological processes in conservation areas: external factors influence land use by zebra (Equus burchelli) in the Okavango Delta. Ecology and Evolution, 3(9), 2795-2805.

Bauer, H. \& Van Der Merwe, S. (2004). Inventory of free-ranging lions Panthera leo in Africa. Oryx, 38(1), 26-31.

Bauer, H., Chapron, G., Nowell, K., Henschel, P., Funston, P., Hunter, L.T., Macdonald, D.W. \& Packer, C. (2015). Lion (Panthera leo) populations are declining rapidly across Africa, except in intensively managed areas. Proceedings of the National Academy of Sciences, 112(48), 14894-14899.

Boyce, M.S., Vernier, P.R., Nielsen, S.E. \& Schmiegelow, F.K. (2002). Evaluating resource selection functions. Ecological Modeling, 157, 281-300.

Brassine, E.I. (2014). The cheetahs of the northern Tuli Game Reserve, Botswana: population estimates, monitoring techniques, and human-predator conflict. M.Sc. thesis. Grahamstown, South Africa: Rhodes University.
Carbone, C., Mace, G.M., Roberts, S.C. \& Macdonald, D.W. (1999). Energetic constraints on the diet of terrestrial carnivores. Nature, 402, 286-288.

Cardillo, M., Mace, G.M., Jones, K.E., Bielby, J., Bininda-Emonds, O.R., Sechrest, W., Orme, C.D.L. \& Purvis, A. (2005). Multiple causes of high extinction risk in large mammal species. Science, 309(5738), 1239-1241.

Cardillo, M., Purvis, A., Sechrest, W., Gittleman, J.L., Bielby, J. \& Mace, G.M. (2004). Human population density and extinction risk in the world's carnivores. PLOS Biology, 2.

DOI: 10.1371/journal.pbio.0020197 pmid: 15252445.

Clark, J.D., Laufenberg, J.S., Davidson, M. \& Murrow, J. (2015). Connectivity among subpopulations of Louisiana black bears as estimated by a step selection function. Journal of Wildlife Management, 9999, $1-14$.

Crawshaw, P.G. \& Quigley, H.B. (1991). Jaguar spacing, activity and habitat use in a seasonally flooded environment in Brazil. Journal of Zoology, 223, 357-370.

Cushman, S.A. \& Lewis, J.S. (2010). Movement behavior explains genetic differentiation in American black bears. Landscape Ecology, 25,1613-1625

Cushman, S.A. (2010). Animal movement data GPS telemetry, autocorrelation and the need for path-level analysis. In S.A. Cushman \& F. Huettmann (Eds), Spatial complexity, informatics, and wildlife conservation (pp. 131-149). New York: Springer.

Davies, A.B., Tambling, C.J., Kerley, G.I. \& Asner, G.P. (2016). Effects of vegetation structure on the location of lion kill sites in African thicket. PLOS ONE, 11(2), e0149098.

De Boer, W.F., Vis, M.J., de Knegt, H.J., Rowles, C., Kohi, E.M., van Langevelde, F., Peel, M., Pretorius, Y., Skidmore, A.K., Slotow, R. \& van Wieren, S.E. (2010). Spatial distribution of lion kills determined by the water dependency of prey species. Journal of Mammalogy, 91(5), 1280-1286.

Dormann, C.F., Elith, J., Bacher, S., Buchmann, C., Carl, G., Carré, G., Marquéz, J.R.G., Gruber, B., Lafourcade, B., Leitão, P.J. \& Münkemüller, T. (2013). Collinearity: a review of methods to deal with it and a simulation study evaluating their performance. Ecography, 36(1), 27-46.

Elliot, N.B., Cushman, S.A., Macdonald, D.W. \& Loveridge, A.J. (2014). The devil is in the dispersers: predictions of landscape connectivity change with demography. Journal of Applied Ecology, 51, 11691178.

Estes, J.A., Terborgh, J., Brashares, J.S., Power, M.E., Berger, J., Bond, W.J., Carpenter, S.R., Essington, T.E., Holt, R.D., Jackson, J.B. \& Marquis, R.J. (2011). Trophic downgrading of planet Earth. Science, 333(6040), 301-306.

Gaylard, A., Owen-Smith, N. \& Redfern, J. (2003). Surface water availability: implications for heterogeneity and ecosystem processes. The Kruger experience: ecology and management of savanna heterogeneity (pp. 171-188). Washington: Island Press.

Fortin, D., Beyer, H.L., Boyce, M.S., Smith, D.W., Duchesne, T. \& Mao, J.S. (2005). Wolves influence elk movements: behavior shapes a trophic cascade 
in Yellowstone National Park. Ecology, 86, 13201330.

Funston, P.J., Mills, M.G.L. \& Biggs, H.C. (2001). Factors affecting the hunting success of male and female lions in the Kruger National Park. Journal of Zoology, 253, 419-431.

Hayward, M.W. \& Kerley, G.I. (2005). Prey preferences of the lion (Panthera leo). Journal of Zoology, 267, 309-322.

Hayward, M.W. \& Slotow, R. (2009). Temporal partitioning of activity in large African carnivores: tests of multiple hypotheses. South African Journal of Wildlife Research, 39(2), 109-125.

Hebblewhite, M., Merrill, E.H. \& McDonald, T.L. (2005). Spatial decomposition of predation risk using resource selection functions: an example in a wolf-elk predator-prey system. Oikos, 111, 101e111.

Hepinstall, J., Marzluff, J. \& Alberti, M. (2008b). Modeling the responses of birds to predicted changes in land cover in an urbanizing region. In J.J. Millspaugh \& F.R. Thompson III (Eds), Models for planning wildlife conservation in large landscapes (pp. 625-659). San Diego, CA, U.S.A.: Elsevier Science.

Holmern, T., Nyahongo, J. \& Røskaft, E. (2007). Livestock loss caused by predators outside the Serengeti National Park, Tanzania. Biological Conservation, 135, 518-526.

Hopcraft, J.G.C., Sinclair, A.R.E. \& Packer, C. (2005). Planning for success: Serengeti lions seek prey accessibility rather than abundance. Journal of Animal Ecology, 75, 559-566.

IUCN (2013). The IUCN Red List of Threatened Species. Version 2013.1 http://www.iucnredlist.org

Jackson, C.R., Power, R.J., Groom, R.J., Masenga, E.H., Mjingo, E.E., Fyumagwa, R.D., Røskaft, E. \& Davies-Mostert, H. (2014). Heading for the hills: risk avoidance drives den site selection in African wild dogs. PLOS ONE, 9(6), p.e99686.

Johnson, D.H. (1980). The comparison of usage and availability measurements for evaluating resource preference. Ecology, 61, 65-71.

Kernohan, B.J., Gitzen, R.A. \& Millspaugh, J.J. (2001). Analysis of animal space use and movements. In J. J. Millspaugh, J. M. Marzluff (Eds), Radio tracking and animal populations (pp. 125-166). San Diego, CA, U.S.A.: Academic.

Kertson, B.N \& Marzluff, J.M. (2011). Improving studies of resource selection by understanding resource use. Environmental Conservation, 38, 18-27.

Kissui, B.M. \& Packer, C. (2004). Top-down population regulation of a top predator: lions in the Ngorongoro crater. Proceedings of the Royal Society of London, 271, 1867-1874.

Kuiper, T.R., Loveridge, A.J., Parker, D.M., Johnson, P.J., Hunt, J.E., Stapelkamp, B., Sibanda, L. \& Macdonald, D.W. (2015). Seasonal herding practices influence predation on domestic stock by African lions along a protected area boundary. Biological Conservation, 191, 546-554.

Lehmann, M.B., Funston, P.J., Owen, C.R. \& Slotow, R. (2008). Feeding behaviour of lions (Panthera leo) on a small reserve. South African Journal of Wildlife Research, 38, 66-78.
Marzluff, J.M., Millspaugh, J.J., Hurvitz, P. \& Handcock, M.S. (2004). Relating resources to a probabilistic measure of space use: forest fragments and Steller's jays. Ecology, 85, 1411-1427.

Mills, G.L \& Gorman, M.L. (1997). Factors affecting the density and distribution of wild dogs in the Kruger National Park. Conservation Biology, 11 , 1397-1406.

Mosser, A. \& Packer, C. (2009). Group territoriality and the benefits of social living in the African lion (Panthera leo). Animal Behavior, 78, 359-370.

Naimi, B. (2015). usdm: Uncertainty Analysis for Species Distribution Models. R package version 1.1-15. https://CRAN.R-project.org/package=usdm

Oriol-Cotterill, A., Macdonald, D.W., Valeix, M., Ekwanga, S. \& Frank, L.G. (2015). Spatiotemporal patterns of lion space use in a human-dominated landscape. Animal Behavior, 101, 27-39.

Otis, D.L. \& White, G.C. (1999). Autocorrelation of location estimates and the analysis of radio tracking data. Journal of Wildlife Management, 63, 1039-1044.

Packer, C., Hilborn, R., Mosser, A., Kissui, B., Borner, M., Hopcraft, G., Wilmshurst, J., Mduma, S. \& Sinclair, A.R. (2005). Ecological change, group territoriality, and population dynamics in Serengeti lions. Science, 307(5708), 390-393.

Petrunenko, Y.K., Montgomery, R.A., Seryodkin, I.V., Zaumyslova, O.Y., Miquelle, D.G. \& Macdonald, D.W. (2016). Spatial variation in the density and vulnerability of preferred prey in the landscape shape patterns of Amur tiger habitat use. Oikos, 125, 66-75

Polis, G.A., Anderson, W.B. \& Holt, R.D. (1997). Toward an integration of landscape and food web ecology: the dynamics of spatially subsidized food webs. Annual Review of Ecology and Systematics, 28(1), 289-316.

Powell, L.A. (2007). Approximating variance of demographic parameters using the delta method: a reference for avian biologists. Condor, 109(4), 949-954.

Purvis, A., Gittleman, J.L., Cowlishaw, G. \& Mace, G.M. (2000). Predicting extinction risk in declining species. Proceedings of the Royal Society of London, Series $B, 267,1947-1952$.

R Core Team (2013). R: A language and environment for statistical computing. R Foundation for Statistical Computing, Vienna, Austria. URL http://www.R-project.org/

Riggio, J., Jacobson, A., Dollar, L., Bauer, H., Becker, M., Dickman, A., Funston, P., Groom, R., Henschel, P., de longh, H. \& Lichtenfeld, L. (2013). The size of savannah Africa: a lion's (Panthera leo) view. Biodiversity and Conservation, 22(1), 17-35.

Riggio, J., Caro, T., Dollar, L., Durant, S.M., Jacobson, A.P., Kiffner, C., Pimm, S.L. \& van Aarde, R.J. (2016). Lion populations may be declining in Africa but not as Bauer et al. suggest. Proceedings of the National Academy of Sciences of the United States of America, 113(2), e107.

Ripple, W.J., Beschta, R.L., Fortin, J.K. \& Robbins, C.T. (2014). Trophic cascades from wolves to grizzly bears in Yellowstone. Journal of Animal Ecology. DOI: 10.1111/1365-2656.12123

Ripple, W.J., Estes, J.A., Beschta, R.L., Wilmers, C.C., Ritchie, E.G., Hebblewhite, M., ... \& Schmitz, O.J. 
(2014). Status and ecological effects of the world's largest carnivores. Science, 343, 1241484. DOI: $10.1126 /$ science. 1241484

Ripple, W.J., Painter, L.E., Beschta, R.L. \& Gates, C. (2010). Wolves, elk, bison and secondary trophic cascades in Yellowstone National Park. Open Ecology Journal, 3, 31-37.

Schaller, G.B. (1972). The Serengeti lion: a study of predator-prey relations. Chicago: University of Chicago Press.

Schiegg, K. (2003). Environmental autocorrelation: curse or blessing? Trends in Ecology and Evolution, 18, 212-214.

Silverman, B.W. (1986). Density estimation for statistics and data analysis (Vol.26). Boca Raton: CRC press.

Slotow, R. \& Hunter, L. (2009). Reintroduction decisions taken at the incorrect social scale devalue their conservation contribution: African lion in South Africa. In M.W. Hayward \& M.J. Somers (Eds), Reintroduction of top-order predators. Oxford: Wiley-Blackwell.

Smuts, G.L., Whyte, I.J. \& Dearlove, T.W. (1977). A mass capture technique for lions. African Journal of Ecology, 15(1), 81-87.

Snyman, A., Jackson, C.R. \& Funston, P.J. (2015). The effect of alternative forms of hunting on the social organization of two small populations of lions Panthera leo in southern Africa. Oryx, 49, 604-610.

Stephens, D.W. \& Krebs, J.R. (1986). Foraging theory. Princeton University Press.

Valeix, M., Hemson, G., Loveridge, A.J., Mills, G. \& Macdonald, D.W. (2012). Behavioural adjustments of a large carnivore to access secondary prey in a human-dominated landscape. Journal of Applied Ecology, 49, 73-81.

Van Dyk, G. \& Slotow, R. (2003). The effects of fences and lions on the ecology of African wild dogs reintro- duced to Pilanesberg National Park, South Africa. African Zoology, 38, 79-94.

Van Orsdol, K.G. (1984). Foraging behaviour and hunting success of lions in Queen Elizabeth National Park, Uganda. African Journal of Ecology, 22, 79-99.

Van Winkle, W. (1975). Comparison of several probabilistic home range models. Journal of Wildlife Management, 39, 118-123.

Wall, J. (2014). Movement Ecology Tools for ArcGIS (ArcMET) v.10.2.2 v2.

Available at: www.movementecology.net (accessed 16 November 2015).

Woodroffe, R. (2000). Predators and people: using human densities to interpret declines of large carnivores. Animal Conservation, 3, 165-173.

Woodroffe, R. (2001). Strategies for carnivore conservation: lessons from contemporary extinctions. In J.L. Gittleman, S. Funk, D.W. Macdonald \& R.K. Wayne (Eds), Carnivore conservation (pp. 61e92). Cambridge, U.K.: Cambridge University Press.

Woodroffe, R. \& Ginsberg, J.R. (1998). Edge effects and the extinction of populations inside protected areas. Science, 280, 2126-2128.

Zeller, K.A. \& Rabinowitz, A. (2011). Using geographic information systems for range-wide species conservation planning. Geographic Information Systems, Hauppauge, NY: Nova Science Publishers, Inc.

Zeller, K.A., McGarigal, K. \& Whiteley, A.R. (2012). Estimating landscape resistance to movement: a review. Landscape Ecology, 27, 777-797.

Zeller, K.A., McGarigal, K., Beier, P., Cushman, S.A., Vickers, T.W. \& Boyce, W.M. (2014). Sensitivity of landscape resistance estimates based on point selection functions to scale and behavioral state: pumas as a case study. Landscape Ecology, 29, 541-557. 